\title{
PERBANDINGAN HASIL BELAJAR FISIKA MATERI LISTRIK STATIS DENGAN METODE INQUIRI DAN METODE EKSPOSITORI PADA MASA PANDEMI SISWA KELAS XII SMA NEGERI 2 BANDAR LAMPUNG TAHUN PELAJARAN 2021/2022
}

\author{
ATO SUHARTO \\ SMA Negeri 2 Bandar Lampung \\ e-mail: ato.sman2bdl@gmail.com
}

\begin{abstract}
ABSTRAK
Rendahnya hasil belajar fisika pada masa pandemi covid-19, dipengaruhi berbagai macam faktor, antara lain kurang tepatnya penggunaan metode dalam menyampaikan materi pelajaran. Hal ini menjadi perhatian khusus dan masalah umum dalam dunia pendidikan. Adapun tujuan diadakan penelitian ini adalah; (1). untuk mengetahui perbedaan rata-rata hasil belajar fisika siswa yang mengikuti pembelajaran dengan menggunakan metode Inquiri dan metode Ekspositori pada materi listrik statis pada masa pandemi. (2). untuk mengetahui hasil belajar yang lebih tinggi antara siswa yang mengikuti pembelajaran dengan menggunakan metode inquiri atau metode ekspositori materi listrik statis pada masa pandemi. Hipotesis dalam penelitian ini adalah, rata-rata hasil belajar fisika dengan menggunakan metode inquiri lebih tinggi jika dibandingkan dengan menggunakan metode ekspositori. Populasi dalam penelitian ini seluruh siswa kelas XII SMA Negeri 2 Bandar Lampung tahun pelajaran 2021/2022 yang terdiri dari sembilan kelas, percontoh dalam penelitian ini adalah dua kelas. Pembelajaran dilakukan secara Blended Learning. Data primer diperoleh dari penilain harian setelah siswa mengikuti proses belajar mengajar pada materi listrik statis. Selanjutnya data dianalisis menggunakan uji normalitas, uji kesamaan dua varians, uji kesamaan dua rata-rata dan uji perbedaan dua rata-rata. Berdasarkan hasil perhitungan data ternyata rata-rata hasil belajar fisika siswa yang mengikuti pembelajaran dengan menggunakan metode inquiri sebesar 84,26 dan rata-rata hasil belajar fisika siswa yang mengikuti pembelajaran dengan menggunakan metode ekspositori sebesar 75,21. Dengan uji t didapatkan perbedaan antara pembelajaran menggunakan metode inquiri dan ekspositori sebesar 9,02 atau 12,03\%. Dari hasil penelitian ini dapat disimpulkan bahwa hasil belajar fisika materi listrik statis siswa yang mengikuti pembelajaran dengan menggunakan metode inquiri lebih tinggi dibandingkan dengan menggunakan metode ekspositori.
\end{abstract}

Kata kunci: Hasil belajar fisika, Listrik statis, Inquiri, Ekspositori, Pademi Covid-19.

\section{PENDAHULUAN}

Pencapaian hasil belajar fisika di SMA Negeri 2 Bandar Lampung pada masa pandemi covid-19 tergolong cukup rendah, secara keseluruhan ada pada rata-rata 74,18. Rendahnya pencapaian hasil belajar ini diharapkan menjadi motivasi khusus bagi pihak sekolah dan guru agar selalu melibatkan siswa dalam setiap proses belajar mengajar. Rendahnya hasil belajar fisika ini berpengaruh juga terhadap proses belajar mengajar di kelas. Dengan demikian, daya tangkap materi kurang, sehingga mempengaruhi hasil belajar yang dicapai siswa. Hal ini terlihat pada hasil belajar fisika materi listrik statis pada semester 1 tahun pelajaran 2020/2021 rataratanya 71,26 (Dokumen penilaian guru kelas XII SMA Negeri 2 Bandar Lampung tahun pelajaran 2020/2021).

Salah satu penyebab rendahnya hasil belajar fisika pada masa pandemi ini adalah kurang tepatnya dalam pemilihan dan penggunaan metode yang digunakan (Sani, 2019). Dalam pembelajaran guru cenderung menggunakan satu macam metode. Kita ketahui penggunaan metode yang kurang tepat dan monoton menjadikan situasi kelas saat proses belajar mengajar jadi membosankan. Dengan situasi ini motivasi siswa untuk belajar kurang dan rendah menyebabkan daya serap pelajaran kurang akhirnya hasil belajarnya rendah. Sehingga tidak dapat dipungkiri pemilihan dan penggunaan metode yang tepat pada masa pandemi akan 
mempengaruhi hasil belajar fisika. Dengan kata lain, untuk meningkatkan hasil belajar diperlukan suatu metode yang dianggap lebih cocok. Penerapan metode inquiri pada masa pandemi ini diyakini dapat meningkatkan motivasi belajar, dengan termotivasi untuk belajar kelas menjadi lebih hidup, penerimaan pelajaran akan maksimal, sehingga menyebabkan prestasinya meningkat.

Berdasarkan latar belakang masalah dan situasi tersebut maka yang menjadi masalah dalam penelitian ini adalah; (1) apakah ada perbedaaan rata-rata hasil belajar fisika siswa yang mengikuti pembelajaran dengan menggunakan metode inquiri dengan metode ekspositori pada materi listrik statis?, (2) metode manakah yang lebih tinggi rata-rata hasil belajar fisikanya, siswa yang mengikuti pembelajaran dengan menggunakan metode inquiri atau dengan metode ekspositori?

Adapun tujuan diadakan penelitian ini adalah; (1). Untuk mengetahui perbedaan ratarata hasil belajar fisika siswa yang mengikuti pembelajaran dengan menggunakan metode Inquiri dan metode Ekspositori pada materi listrik statis pada masa pandemi. (2). Untuk mengetahui hasil belajar yang lebih tinggi antara siswa yang mengikuti pembelajaran dengan menggunakan metode inquiri atau metode ekspositori materi listrik statis pada masa pandemi.

Hasil penelitian ini diharapkan dapat dipergunakan sebagai bahan; (1). Informasi bagi guru dan calon guru fisika dalam memilih dan menggunakan metode pembelajaran yang cocok untuk membangkitkan dan merangsang motivasi belajar siswa pada masa pandemi. (2). Pertimbangan bagi guru dan calon guru fisika dalam mengembangkan pelajaran fisika di sekolah terutama pada masa pandemi.

Untuk menghindari kesalahan dalam penafsiran, batasan masalah dalam penelitian ini adalah sebagai berikut: (1). Perbandingan yang dimaksud adalah perbandingan tentang perbedaan dan kesamaan hasil belajar fisika siswa yang mengikuti pembelajaran dengan menggunakan metode inquiri dan metode ekspositori. (2). Hasil belajar adalah nilai yang diperoleh dari proses belajar mengajar fisika pada materi listrik statis yang dinyatakan dalam bentuk angka-angka dengan mencari rata-ratanya. (3). Metode inquiri adalah suatu metode dimana siswa dalam satu kelas dibagi menjadi beberapa kelompok dan masing-masing kelompok mendapatkan permasalahan yang harus dipecahkan bersama-sama. (4). Metode Ekspositori adalah suatu metode dimana guru berperan aktif dalam memberikan informasi mengenai bahan pelajaran siswa, siswa hanya mendengarkan dan mencatat apa yang dikatakan guru.

Metode ekspositori merupakan metode pembelajaran klasikal yang dalam penyampaian guru hanya memberikan hal-hal yang umum, konsep disertai contoh dengan harapan siswa belajar dari informasi yang diberikan, seperti yang dinyatakan oleh Ruseffendi sebagai berikut: "Pada metode ekspositori kegiatan diawali oleh guru memberikan informasi (ceramah) dengan menerangkan suatu keterampilannya mengenai pola, aturan tentang konsep, siswa bertanya guru memeriksa apakah siswa sudah mengerti atau belum, guru memberikan contoh soal aplikasi konsep itu, siswa menyelesaikannya, kegiatan diakhiri dengan siswa mencatat materi yang diterangkan." (Ruseffendi, 1980). Terkait metode ekspositori ini, Sudjana juga menerangkan sebagai berikut: "Dalam pembelajaran metode ekspositori siswa dipandang sebagai obyek yang menerima apa yang diberikan oleh guru. Biasanya guru menyampaikan informasi mengenai bahan pembelajaran dalam bentuk penjelasan dan penuturan secara lisan" (Sudjana, 1989).

Sedangkan pelaksanaan metode inquirí, dapat dilakukan dengan memberikan tugas dan mendiskusikan tugas yang telah diberikan, sehingga siswa dapat memberikan dan menyusun jawaban dari masing-masing masalah atau hal-hal yang tidak begitu jelas pengertiannya dalam bimbingan guru. Pada metode inquiri mengandung proses mental yang tinggi tingkatannya seperti; (1). merumuskan masalah, (2). melakukan eksperimen, (3). menyajikan data, (4). menganalisis data, (5). menyimpulkan, (6). serta memberikan sikap obyektif (Delong, 2009). Tujuan guru menggunakan metode ini adalah agar siswa terangsang oleh tugas dan aktif mencari serta meneliti sendiri permasalahan itu. 


\section{METODE PENELITIAN}

Penelitian dilaksanakan di SMA Negeri 2 Bandar Lampung selama dua bulan yaitu bulan Agustus 2021 dan September 2021. Metode yang digunakan dalam penelitian ini adalah Quasi Eksperimen. Stouffer dan Campbell merumuskan eksperimen kuasi (quasi-experiment) sebagai eksperimen yang memiliki perlakuan, pengukuran dampak, unit eksperimen, namun tidak menggunakan penugasan acak untuk menciptakan pembandingan dalam rangka menyimpulkan perubahan yang disebabkan perlakuan (Hastjarjo, 2008). Populasi dalam penelitian ini adalah seluruh siswa kelas XII semester 1 SMA Negeri 2 Bandar Lampung tahun pelajaran 2021/2022, terdiri dari sembilan kelas dan 318 siswa. Percontoh dalam penelitian ini adalah sebanyak dua kelas yaitu kelas XII MIPA-4 dan XII MIPA-6 dalam pengambilan percontoh menggunakan teknik radom sampling didapatkan kelas yang terpilih sebagai percontoh disebut kelas A dan kelas B. Kegiatan pembelajaran dilakukan dengan cara Blended Learning, dimana setiap siswa memiliki kesempatan untuk belajar secara on-line dan off-line secara bergantian berdasarkan nomor absen ganjil dan genap. Sedangkan platform yang digunakan dalam pembelajaran yang dilakukan secara on-line pada penelitian masa pandemi ini adalah Zoom Meeting, Google Class Room (GCR), WhatsApp (WA), e-mail, Google Form, Facebook, Youtube, beberapa link pembelajaran dan lain-lain. Sedangkan pertemuan yang dilakukan dengan cara Pertemuan Tatap Muka (PTM) Terbatas dengan menerapkan protokol kesehatan yang sangat ketat (Kemenkes, 2020)

Jenis data yang digunakan dalam penelitian pada masa pandemi ini adalah Data Primer yang bersifat kuantitatif, yang diperoleh dari hasil penilaian harian yang diberikan pada siswa dari kelompok A dan kelompok B (Sugiyono, 2016). Data dalam penelitian ini diperoleh dari penilaian harian yang diberikan setelah menyelesaikan materi listrik statis. Teknik yang digunakan dalam pengumpulan data pada penelitian ini dilakukan dengan cara mengadakan penilaian harian. Penilaian dilakukan sebanyak satu kali setelah materi listrik statis selesai diberikan. Penilaian dilaksanakan dalam bentuk pilihan ganda sebanyak 25 butir soal. Langkahlangkah yang ditempuh adalah sebagai berikut: (1). Membuat model jawaban yang dikehendaki. (2). Menentukan skor untuk tiap bagian sesuai dengan tingkat kebenarannya. (3). Membandingkan jawaban siswa tiap bagian dengan kunci jawaban dan memberikan skor, dan (4). Menjumlahkan skor yang diperoleh siswa dari tiap-tiap bagian (Darmawan, 2014)

\section{HASIL DAN PEMBAHASAN}

\section{Hasil Penelitian}

Data penelitian pada masa pandemi ini adalah data primer yang diperoleh dari nilai penilaian harian siswa setelah mengikuti proses belajar mengajar pada materi konsep listrik statis. Sebelum soal digunakan untuk mengambil data, sebagai alat ukur terlebih dahulu diujicobakan pada populasi diluar percontoh yang diambil guna menguji validitasnya. Hasil ujicoba soal dianalisis korelasi "Produck moment" (Arikunto, 1993), didapatkan reliabilitasnya $=0,843$ termasuk kategori tinggi.

Uji Normalitas (Sudjana, 1992). Sebelum melakukan pengujian selanjutnya, data diuji normalitasnya. Hal ini dilakukan untuk mengetahui apakah percontoh berasal dari populasi yang berdistribusi normal atau tidak. Hasil uji normalitas pada taraf nyata $(\alpha) 1 \%$ pada perlakuan menggunakan metode inquiri didapatkan harga $\mathrm{L}_{\mathrm{o}}=0,085$ dan $\mathrm{L}_{\text {tab }} 0,150$, karena harga $\mathrm{L}_{\mathrm{o}}<\mathrm{L}_{\mathrm{tab}}$ maka data dikategorikan berdistribusi normal. Sedangkan pada perlakuan menggunakan metode ekspositori didapatkan harga $\mathrm{L}_{\mathrm{o}}=0,096$ dan $\mathrm{L}_{\mathrm{tab}}=0,150$, karena $\mathrm{L}_{\mathrm{o}}<$ $\mathrm{L}_{\text {tab }}$ maka data dikategorikan berdistribusi normal. Hasil uji normalitas dapat disimpulkan kedua data berdistribusi normal dinyatakan dengan $\mathrm{L}_{\mathrm{o}}<\mathrm{L}_{\text {tab. }}$.

Tabel 1. Uji Normalitas Pada Dua Perlakuan

\begin{tabular}{cccc}
\hline \hline Perlakuan & $\mathrm{L}_{\mathrm{o}}$ & $\mathrm{L}_{\mathrm{tab}}$ & Status Data \\
\hline $\mathrm{A}$ & 0,085 & 0,150 & Normal \\
$\mathrm{B}$ & 0,096 & 0,150 & Normal \\
\hline
\end{tabular}


Uji Kesamaan Dua Varians. Uji kesamaan dua varians untuk mengetahui varians dari kedua populasi sama besar atau tidak sama besar. Uji kesamaan dua varians dilakukan dengan kriteria sebagai berikut.

a. Rumusan Hipotesis

$H_{\mathrm{O}}=\sigma_{1}^{2}=\sigma_{2}^{2}$ Varians kedua populasinya sama besar.

$\mathrm{H}_{1}=\sigma_{1}^{2} \neq \sigma_{2}^{2}$ Varians kedua populasinya tidak sama besar.

b. Kriteria Uji

Tolak $\mathrm{H}_{\mathrm{o}}$ jika $\mathrm{F}_{\text {hit }} \geq \mathrm{F}_{\text {tab }}$ dan terima untuk harga lainnya.

Dari hasil perhitungan varians kelompok A dengan menggunakan metode inquiri sebesar $\mathrm{D}^{2}{ }_{1}$ $=178,2$ sedangkan varians pada kelompok B dengan menggunakan metode ekspositori sebesar $\mathrm{S}_{2}^{2}=151,38$.

Selanjutnya dengan menggunakan uji $\mathrm{F}$ didapat $\mathrm{F}_{\text {hit }}=1,177$ dan $\mathrm{F}_{\mathrm{tab}}=1,68$ pada $\sigma=1 \%$ karena $\mathrm{F}_{\text {hit }}<\mathrm{F}_{\text {tab }}$ atau 1,177 $<1,68$ dengan demikian disimpulkan varians populasi dari kedua data adalah tidak sama.

\section{Tabel 2. Uji Kesamaan Dua Varians}

\begin{tabular}{cccc}
\hline \hline Perlakuan & $\mathrm{F}_{\text {hit }}$ & $\mathrm{F}_{\text {tab }}$ & Status Data \\
\hline $\mathrm{A} \| \mathrm{B}$ & 1,177 & 1,68 & Tidak sama \\
\hline
\end{tabular}

Uji Kesamaan Dua Rata-rata. Uji kesamaan dua rata-rata untuk menentukan apakah pada masa pandemi ada perbedaan rata-rata atau tidak antara perlakuan dengan menggunakan metode inquiri dengan metode ekspositori, atau pada perlakuan A dengan Perlakuan B.

a. Rumusan Hipotesisnya

$\mathrm{H}_{\mathrm{o}}: \mu_{1}=\mu_{2}$ tidak ada perbedaan rata-rata hasil belajar pada masa pandemi dengan menggunakan metode inquiri dengan menggunakan metode ekspositori.

$\mathrm{H}_{1}: \mu_{1} \neq \mu_{2}$ terdapat perbedaan rata-rata hasil belajar pada masa pandemi dengan menggunakan metode inquiri dengan menggunakan metode ekspositori.

b. Kriteria Uji

$\sigma 1$ Jika $\sigma 1 \ddagger \sigma 2$ ( $\sigma$ tidak dikertahui) terima $\mathrm{H}_{\mathrm{o}}$ jika

$-\frac{w_{1} t_{1}+w_{2} t_{2}}{w_{1}+w_{2}}<\mathrm{t}_{\text {hit }}<\frac{w_{1} t_{1}+w_{2} t_{2}}{w_{1}+w_{2}}$

dan ditolak untuk nilai t lainnya.

Jika $\sigma 1=\sigma 2$ (tidak diketahui) terima $\mathrm{H}_{\mathrm{o}}$ jika

$-\mathrm{t}(1-1 / 2 \sigma)\left(\mathrm{n}_{1}+\mathrm{n}_{2}-1\right)>\mathrm{t}_{\text {hit }}$

$\mathrm{t}(1-1 / 2 \sigma)\left(\mathrm{n}_{1}+\mathrm{n}_{2}-2\right)$ dan ditolak untuk nilai t lainnya.

Dari perhitungan didapat $\mathrm{t}_{\mathrm{tab}}=1,68$ dan $\mathrm{t}_{\text {hit }}=6,9$. karena $-\mathrm{t}_{\text {hit }}<\mathrm{t}_{\mathrm{tab}}<\mathrm{t}_{\text {hit }}=1,68<6,9<1,68$ dapat disimpulkan rata-rata hasil belajar fisika siswa yang mengikuti pembelajaran dengan menggunakan metode inquiri pada masa pandemi lebih tinggi jika dibandingkan dengan menggunakan metode ekspositori. Persamaan yang berlaku adalah $\mathrm{H}_{1}: \sigma_{1}>\sigma_{2}$.

Tabel 3. Uji Kesamaan Dua Rata-rata

\begin{tabular}{cccc}
\hline \hline Perlakuan & thit & $\mathrm{t}_{\text {tab }}$ & Status Data \\
\hline $\mathrm{A} \| \mathrm{B}$ & 6,9 & 1,68 & $\mathrm{~A}>\mathrm{B}$ \\
\hline
\end{tabular}

Uji Perbedaan Dua Rata-rata. Uji perbedaan dua rata-rata untuk mengetahui pada masa pandemi mana yang lebih tinggi rata-rata hasil belajar antara siswa yang mengikuti pembelajaran dengan menggunakan metode inquiri atau menggunakan metode ekspositori.

a. Rumusan Hipotesisnya 
$\mathrm{H}_{\mathrm{o}}: \mu_{1}>\mu_{2}$ Hasil belajar siswa yang mengikuti pembelajaran dengan menggunakan metode inquiri pada masa pandemi lebih tinggi jika dibandingkan dengan menggunakan metode ekspositori.

$\mathrm{H}_{1}: \mu_{1}<\mu_{2}$ Hasil belajar siswa yang mengikuti pembelajaran dengan menggunakan metode inquiri pada masa pandemi lebih rendah jika dibandingkan dengan yang menggunakan metode ekspositori.

b. Kriteria Uji

Tolak $\mathrm{H}_{\mathrm{o}} \mathrm{jika}$

$\mathrm{t}_{\text {hit }}>\frac{w_{1} t_{1}+w_{2} t_{2}}{w_{1}+w_{2}}$

dan terima untuk nilai t lainnya.

Dari data perhitungan didapatkan harga $t_{\text {hit }}=6,9$ dan $t_{\text {tab }}=1,68$, karena $t_{\text {hit }}>t_{\text {tab }}$ atau $6,9>1,68$ dapat disimpulkan hasil belajar fisika siswa yang mengikuti pembelajaran dengan menggunakan metode inquiri pada masa pandemi lebih tinggi jika dibandingkan dengan menggunakan metode ekspositori.

Tabel 4. Uji Uji Perbedaan Dua Rata-rata

\begin{tabular}{cccc}
\hline \hline Perlakuan & $\mathrm{t}_{\text {hit }}$ & $\mathrm{t}_{\text {tab }}$ & Status Data \\
\hline $\mathrm{A} \| \mathrm{B}$ & 6,9 & 1,68 & $\mathrm{~A}>\mathrm{B}$ \\
\hline
\end{tabular}

\section{Pembahasan}

Pada langkah pengujian normalitas dengan taraf nyata $(\alpha) 1 \%$ didapatkan $\mathrm{L}_{\mathrm{o}}=0,085$ dan $\mathrm{L}_{\mathrm{tab}}=0,150$ untuk siswa yang mengikuti pembelajaran dengan menggunakan metode inquirí pada masa pandemi, $\mathrm{L}_{\mathrm{o}}=0,096$ dan $\mathrm{L}_{\mathrm{tab}}=0,150$ untuk siswa yang mengikuti pembelajaran pada masa pandemi dengan menggunakan metode ekspositori. Karena $\mathrm{L}_{\mathrm{o}}<\mathrm{L}_{\mathrm{tab}}$ berlaku untuk metode inquiri maupun metode ekspositori, 0,085 $<0,150$ dan 0,096 $<0,150$ dapat disimpulkan bahwa data berdistribusi normal. Perbedaan hasil belajar pada masa pandemi antara siswa yang mengikuti pembelajaran dengan menggunakan metode inquiri dan metode ekspositori disebabkan karena perlakuan yang berbeda terhadap proses belajar mengajar yang dilakukan guru.

Hal ini sejalan dengan pendapat Imam Ghazali (Apriyono, 2013) bahwa "Data yang berdistribusi normal akan memperkecil kemungkinan terjadinya bias hasil penelitian. Jadi uji normalitas sejatinya untuk menguji penelitian yang kita lakukan, sebagai perbandingan antara data penelitian yang kita lakukan dengan data riil yang berdistribusi normal yang memiliki mean dan standar deviasi yang sama dengan data penelitian yang telah kita peroleh. Karena data yang berdistribusi normal memiliki sebaran pola yang normal/terarah dan merupakan syarat untuk melakukan parametric-test.

Selanjutnya pada uji kesamaan dua varians yang digunakan untuk mengetahui varians dari kedua populasi sama besar atau tidak sama besar. Dari hasil perhitungan varians kelompok A dengan menggunakan metode inquiri sebesar $\mathrm{D}^{2}{ }_{1}=178,2$, sedangkan varians pada kelompok $\mathrm{B}$ dengan menggunakan metode ekspositori sebesar $\mathrm{S}^{2}{ }_{2}=151,38$. Selanjutnya dengan menggunakan uji $\mathrm{F}$ didapat $\mathrm{F}_{\text {hit }}=1,177$ dan $\mathrm{F}_{\text {tab }}=1,68$ pada $\sigma=1 \%$ karena $\mathrm{F}_{\text {hit }}<\mathrm{F}_{\text {tab }}$ atau 1,177 $<$ 1,68 dengan demikian disimpulkan bahwa varians populasi dari kedua data adalah tidak sama.

Hal yang sama juga dikemukakan oleh Supardi, bahwa, "Uji kesamaan dua varians digunakan untuk menguji apakah sebaran data tersebut homogen atau tidak, dengan membandingkan dua variansnya. Jika dua kelompok data atau lebih mempunyai varians yang sama besarnya, maka uji homogenitas tidak perlu dilakukan lagi karena datanya sudah dianggap homogen. Uji homogenitas dapat dilakukan apabila kelompok data tersebut dalam distribusi normal" (Supardi, 2017).

Selanjutnya pada uji kesamaan dua rata-rata yang digunakan untuk menentukan apakah pada masa pandemi ada perbedaan rata-rata atau tidak antara perlakuan dengan menggunakan 
metode inquiri dengan metode ekspositori, atau pada perlakuan A dengan Perlakuan B. Dari perhitungan didapat $\mathrm{t}_{\mathrm{tab}}=1,68$ dan $\mathrm{t}_{\text {hit }}=6,9$. karena $-\mathrm{t}_{\text {hit }}<\mathrm{t}_{\text {tab }}<\mathrm{t}_{\text {hit }}=1,68<6,9<1,68$ dapat disimpulkan rata-rata hasil belajar fisika siswa yang mengikuti pembelajaran dengan menggunakan metode inquiri pada masa pandemi lebih tinggi jika dibandingkan dengan menggunakan metode ekspositori.

Selanjutya pada uji perbedaan dua rata-rata. Uji perbedaan dua rata-rata dilakukan untuk untuk mengetahui pada masa pandemi mana yang lebih tinggi rata-rata hasil belajar antara siswa yang mengikuti pembelajaran dengan menggunakan metode inquiri atau menggunakan metode ekspositori. Dari data perhitungan didapatkan harga $\mathrm{t}_{\text {hit }}=6,9$ dan $\mathrm{t}_{\mathrm{tab}}=1,68$, karena $\mathrm{t}_{\text {hit }}$ $>\mathrm{t}_{\mathrm{tab}}$ atau 6,9>1,68 dapat disimpulkan hasil belajar fisika siswa yang mengikuti pembelajaran dengan menggunakan metode inquiri pada masa pandemi lebih tinggi jika dibandingkan dengan menggunakan metode ekspositori.

Penelitian dilakukan pada masa pandemi covid-19. Kata pandemi berasal dari bahasa Yunani, "pan" yang artinya "semua" dan "demos" yang berarti "orang-orang" Pandemi ini biasa digunakan untuk merujuk pada epidemi yang luas penyakit menular di seluruh negara, satu atau lebih benua pada waktu yang bersamaan (Education, 2020). Menurut Kamus Besar Bahasa Indonesia $(\mathrm{KBBI})$ pandemi berarti wabah penyakit yang terjangkit secara meluas dalam waktu yang serempak, (KBBI, 2020).

Definisi pandemi yang diterima secara internasional seperti yang muncul dalam Kamus Epidemiologi adalah langsung dan terkenal: "epidemi yang terjadi di seluruh dunia, atau di wilayah yang sangat luas, melintasi batas internasional dan biasanya mempengaruhi sejumlah besar orang" (Nadzhiroh, 2017). Berdasarkan definisi-definisi tersebut, pandemi dapat dikatakan sebagai sebuah keadaan di suatu negara atau beberapa negara yang secara bersamaan terjangkit wabah yang sama, bisa itu berupa virus ataupun penyakit lainnya yang berbahaya dan mematikan.

Corona virus merupakan suatu kelompok virus yang dapat menyebabkan penyakit pada hewan atau manusia. Beberapa jenis corona virus diketahui menyebabkan infeksi saluran nafas pada manusia mulai dari batuk pilek hingga yang lebih serius seperti Middle East Respiratory Syndrome (MERS) dan Severe Acute Respiratory Syndrome (SARS) (Schwartz, 2020). Awal mula penyakit yang disebabkan corona virus berasal pada Kota Wuhan, China pada akhir Desember 2019. Corona virus adalah virus yang beredar di antara hewan dengan beberapa di antaranya juga diketahui menginfeksi manusia. Kelelawar dianggap sebagai inang alami dari virus-virus ini, tetapi beberapa spesies hewan lain juga diketahui bertindak sebagai sumber. Sebagai contoh, Middle East Respiratory Syndrome Coronavirus (MERS-CoV) ditransmisikan ke manusia dari unta, dan Severe Acute Respiratory Syndrome Coronavirus-1 (SARS-CoV-1) ditransmisikan ke manusia dari kucing luwak. Informasi lebih lanjut tentang corona virus dapat ditemukan di lembar fakta $E C D C$, (Kemenkes RI, 2020).

Kata belajar dapat didefiniskan sebagai suatu proses usaha yang dilakukan oleh individu, untuk memperoleh suatu perubahan tingkah laku yang baru secara keseluruhan sebagai hasil dari pengalaman melalui interaksi dengan lingkungannya, seperti diungkapkan (Sardiman, 1994) bahwa: "Secara umum belajar boleh dikatakan juga sebagai suatu proses interaksi antara diri manusia dengan lingkungannya, yang mungkin berjudul pribadi, fakta, konsep ataupun teori" Menurut Adi bahwa: "Seseorang baru dapat dikatakan belajar bila sudah terjadi perubahan tingkah laku yang relatif permanen pada dirinya, dimana perubahan itu terjadi karena latihan ataupun penglaman dan bukan merupakan tumbuh kembang alamiah (natural) saja" (Adi, 1994).

Proses belajar mengajar pada masa pandemi dengan menggunakan metode inquiri siswa terlihat lebih aktif, kreatif, termotivasi dan terangsang untuk mengungkapkan pendapatnya saat diskusi kelompok. Saat diskusi siswa cenderung untuk menemukan dan memcahkan jawaban sendiri. Dengan cara ini daya serap dan daya ingat siswa akan lebih tinggi. Hal ini sesuai dengan ungkapan (Roestiyah, 1988) bahwa pelaksanaan metode inquiri pada masa pandemi dimana 
guru membagi tugas meneliti suatu masalah di kelas, siswa dibagi menjadi beberapa kelompok masing-masing kelompok mendapatkan tugas tertentu yang harus dikerjakan.

Pada materi konsep listrik statis pembelajaran dengan menggunakan metode ekspositori pada masa pandemi, pelaksanaannya guru yang berperan aktif memberikan materi pelajaran sedangkan siswa hanya mendengar dan mencatat uraian-uraian yang disampaikan guru. Kondisi ini menuntut siswa cenderung pasif dalam menerima materi atau informasi sehingga hasilnya kurang memuaskan, sesuai dengan pendapat Nasution bahwa pada pelaksanaan metode ekspositori guru yang berperan aktif dalam memberikan informasi materi pelajaran, siswa hanya mendengar dan mencatat apa yang diucapkan guru (Nasution, 1992). Dalam pelaksanaan metode ekspositori pada masa pandemi ditemui adanya perbedaan di dalam kelas, perbedaan itu mengakibatkan penerima informasi ada yang cepat dan ada pula yang lambat. Konsep listrik statis juga merupakan salah satu konsep yang memerlukan penalaran dan daya khayal yang tinggi. Oleh karena itu penyampaian materi listrik statis diusahakan menggunakan metode yang sifatnya merangsang siswa untuk belajar salah satu metode yang tepat yaitu metode inquiri karena mempunyai kelebihan-kelebihan sehingga hasilnya akan baik.

Sehubungan dengan pemilihan metode mengajar (Djayadisastra, 1984) menyatakan: "mengenai penggunaan suatu metode mengajar, gurulah sosok yang paling bertanggung jawab, sebab motif dan gairah belajar pada murid harus selalu dapat dibangkitkan dan dikembangkan. Hal ini hanya mungkin bila guru dapat menggunakan metode yang tepat". Metode inquiri berasal dari bahasa Inggris "Inquiry" yang berarti penyelidikan. Dalam pendidikan pendekatan inquiri ini merupakan suatu pendekatan dimana siswa mencari kebenaran pengetahuan atau informasi tentang sesuatu, mengadakan penyelidikan secara eksperimen, mencari jawaban atas dasar pertanyaan mereka sendiri menjadi tanggung jawab siswa, sebab kondisi belajar didapat dari pengalaman langsung dengan fenomena ilmiah. Metode inquiri dimulai dengan memberikan teka-teki, hal ini akan memotivasi siswa untuk mencari pemecahan masalah dimana guru tidak lagi mendominasi dalam kegiatan belajar siswa, tetapi lebih banyak membimbing dan memberi kebebasan belajar kepada siswa. Pada pelaksanaanya, metode inquiri sebagaimana diungkapkan oleh Anam sebagai berikut: "Guru membagi tugas meneliti suatu masalah di kelas, siswa dibagi menjadi beberapa kelompok masing-masing kelompok mendapatkan tugas tertentu yang harus dikerjakan. Kemudian mereka meneliti atau membahas tugasnya di dalam kelompok" (Anam, 2017).

Keunggulan-keunggulan metode inquiri menurut (Roestiyah, 1988) adalah sebagai berikut: (1). "Dapat membentuk dan mengembangkan "self konsep" pada diri siswa, sehingga dapat dimengerti tentang konsep dasar ide-ide yang lebih tinggi. (2). Membantu dalam mempergunakan ingatan dan transfer pada situasi proses belajar mengajar yang baru. (3). Mendorong siswa untuk berfikir intuitif, bekerja atas dasar inisiatif sendiri, bersikap obyektif jujur dan terbuka. (4). Mendorong siswa untuk berfikir intuitif dan merumuskan hipotensinya sendiri. (5). Memberikan kepuasan yang bersifat intrinsik. (6). Situasi proses belajar menjadi lebih tinggi merangsang. (7). Dapat mengembangkan kecakapan atau bakat individu. (8). Memberikan kebebasan siswa untuk bekerja sendiri. (9). Siswa dapat menghindari dari caracara berfikir tradisional. (10). Dapat memberikan waktu pada siswa secukupnya sehingga dapat mengasimilasi mengakomodasi informasi"

Berdasarkan uraian dan pendapat para ahli mengenai penggunaan metode inquiri di atas dapat disimpulkan bahwa metode inquiri dianggap metode yang paling cocok untuk meningkatkan motivasi keterampilan, gairah dan merangsang sikap intelektual siswa dimana pada pelaksanaannya siswa yang beperan aktif.

Sedangkan pandangan tentang metode ekspositori menunjukan bahwa pada proses belajar mengajar dengan metode ekspositori hanya mendengarkan keterangan dari guru. Penyebaran pengetahuan dikontrol dan ditentukan oleh guru atau pengajar. Siswa dipandang sebagai obyek yang menerima apa yang diberikan guru,sehingga potensi yang ada dalam diri siswa tidak dapat berkembang secara optimal,yang dapat meneyebabkan siswa menjadi pasif. Hal ini menyebabkan keterampilan berpikir siswa tidak bertambah dan pengertian yang 
diperoleh siswa tidak mendalam karena hanya mendorong siswa unutk menghafal. Uraian di atas dapat disimpulkan bahwa metode ekspositori adalaj suatu metode mengajar yang terpusat pada guru. Guru selalu aktif sedangkan siswa kelihatan pasif, karena selalu menerima apa yang diberikan guru dalam mengajar.

Langkah-langkah proses pembelajaran yang menggunakan metode ekspositori sebagai berikut: (1). Guru memberikan penjelasan tentang materi yang akan dipelajari secara sekaligus. (2). Guru memberikan informasi pada bagian yang diperlukan. Misalnya pada saat permulaan pelajaran, pada topik yang baru, pada waktu memberikan contoh-contoh soal dan sebagainya. (3). Guru menerangkan suatu konsep serta aturan-aturan tentang konsep tersebut. (4). Siswa diberikan kesempatan untuk bertanya, bagian mana yang belum dimengerti. (5). Guru memberikan contoh-contoh soal aplikasi konsep yang telah diajarkan,selanjutnya meminta siswa menjelaskan soal-soal di papan tulis atau di buku. (6). Siswa mencatat materi yang telah disampaikan.

Kebaikan-kebaikan dari metode ekspositori adalah sebagai berikut: (1). Penyajian informasi/materi kepada siswa cepat dan efektif. (2). Meringankan tugas guru karena guru tidak merancang dan membuat LKS. Adapun kekurangan dari metode ekspositori adalah sebagai berikut: (1). Sukar bagi siswa untuk selalu mengkonsentrasikan perhatian terhadap keteranganketerngan guru, apalagi kalau metode ini digunakan pada siang hari atau jam-jam terakhir. (2). Kurangnya aktifitas siswa (aktifitas guru lebih banyak). (3). Kurang membimbing siswa secara baik ke arah pengembangan konsep, prinsip maupun keterampilan.

Berdasarkan uraian dan pendapat para ahli mengenai penggunaan metode ekspositori, di atas dapat disimpulkan bahwa metode ekspositori memiliki kadar cara belajar siswa aktif yang cukup rendah. Bagaimana mungkin siswa dapat melakukan kegiatan kalau mereka hanya sebagai penerima informasi materi pelajaran yang diberikan oleh guru.

Dari beberapa pendapat para ahli tersebut di atas dan dari analisa data hasil belajar fisika siswa kelompok A yang mengikuti pembelajaran dengan menggunakan metode inquiri pada masa pandemi rata-rata nilai sebesar 84,23 sedangkan hasil belajar fisika pada kelompok B dengan menggunakan metode ekspositori pada masa pandemi sebesar $=75,21$. Perbedaan ratarata sebesar 9,02 atau 12,68\%, hal ini menunjukkan bahwa rata-rata hasil belajar fisika siswa yang mengikuti pembelajaran dengan menggunakan metode inquiri pada masa pandemi ratarata nilainya lebih tinggi jika dibandingkan dengan menggunakan metode ekspositori.

\section{KESIMPULAN}

Dari data dan pembahasan yang menjadi kesimpulan penelitian adalah: (1). Ada perbedaan rata-rata hasil belajar fisika pada masa pandemi siswa yang mengikuti pembelajaran dengan menggunakan metode inquiri dengan siswa yang mengikuti pembelajaran dengan menggunakan metode ekspositori. (2). Rata-rata hasil belajar fisika siswa yang mengikuti pembelajaran pada masa pandemi dengan menggunakan metode inquiri $(84,26)$ lebih tinggi 9,02 atau $12,03 \%$ dibandingkan dengan rata-rata hasil belajar fisika siswa yang mengikuti pembelajaran dengan menggunakan metode ekspositori $(75,21)$.

Dari kesimpulam di atas, dalam rangka meningkatkan hasil belajar siswa khususnya mata pelajaran fisika pada masa pandemi disarankan sebagai berikut: (1). Dalam kegiatan proses belajar mengajar sebaiknya guru memilih dan menggunakan metode pembelajaran yang tepat dan sesuai dengan materi pelajaran yang akan disampaikan, salah satunya metode inquiri. (2). Guru berusaha untuk selalu menumbuhkan motivasi siswa agar selalu berusaha meningkatkan daya tarik terhadap pelajaran fisika. (3). Guru berusaha untuk selalu aktif dalam proses belajar mengajar fisika dan mengikutsertakan keterlibatan siswa.

\section{DAFTAR PUSTAKA}

Adi, Isbandi Rukminto. (1994). Psikologi Pekerjaan Sosial dan Ilmu Kesejahteraan Sosial, Dasar-dasar Pemikiran. Jakarta: Rajawali Press. 
Anam, Khoirul. (2017). Pembelajaran Berbasis Inkuiri Metode dan Aplikasi. Yogyakarta: Pustaka Pelajar.

Arikunto, Suharsimi. (2013). Dasar-Dasar Evaluasi Pendidikan. Jakarta: Bumi Aksara.

Delong, J. (2009). Pengaruh Model Pembelajaran Inquiry. The Center For Teaching Excellence, United States.

Djayadisastra. (1984). Metode Pembelajaran Dalam Pendidikan. Jakarta: Bina Aksara.

Education, World Bank Group. (2020). "Educational Policies In The Covid-19 Pandemic: What Can Brazil Learn From The Rest of The World?".

Hastjarjo, Dicky. (2008). Ringkasan buku Cook \& Campbell. (1979). Quasi-Experimentation: Design \& Analysis Issues for Field Settings. Houghton Mifflin Co.

Kamus Besar Bahasa Indonesia (KBBI). (2020). https://kbbi.kemdikbud.go.id/entri/pandemi 23 April 2020.

Kesehatan Republik Indonesia, Kementrian. (2020). Situasi https://www.kemkes.go.id/. 7 April 2020.

Nadzhiroh, Faridatun. (2017). “Analisa Efektifitas Sistem Pembelajaran Berbasis E- Learning”, Jurnal Ilmu Komputer Dan Desain Komunikasi Visual (Jikdiskomvis). Vol 2, 2017.

Nasution, S. (1992). Teknologi Pendidikan. Bandung: Jemars.

Roestiyah N. K. (1988). Strategi Belajar Mengajar. Jakarta: Bina Aksara.

Ruseffendi, E.T. (1980). Seri Pembelajaran Matematika Modern Untuk Orang Tua Murid, Guru dan SPG. Bandung: Tarsito.

Sani, Ridwan Abdullah. (2019). Strategi Belajar Mengajar. Depok : PT. Raja Grafindo Persada.

Sardiman. (1994). Motivasi Belajar Mengajar (Pedoman Bagi Guru dan Calon Guru). Jakarta: Rajawali Press.

Schwartz, Andrew M, dkk. (2020). "Managing Resident Workforce and Education During the COVID-19 Pandemic Evolving Strategies and Lessons Learned" Journal of Bone and Joint Surgery.

Sudjana, Nana. (1989). Cara Belajar Siswa Aktif Dalam Proses Belajar Mengajar. Bandung: Sinar Baru.

Sudjana. (1992). Metode Statiska. Bandung: Tarsito.

Sugiyono. (2016). Metode Penelitian Pendidikan Pendekatan Kuantitatif, Kualitatif, dan R\&D (Research and Development). Cetakan ke-23. Bandung: Alfabeta.

Supardi. (2017). Statistik Penelitian Pendidikan. Depok: PT Raja Grafindo Persada. 